\author{
Waldemar Szulc \\ mgr inż. \\ Instytut Kolejnictwa Ośrodek Eksploatacji Toru Doświadczalnego \\ wszulc@ikolej.pl
}

\title{
Marek Krużyński
}

Prof. dr hab. inż.

Politechnika Wrocławska, Wydział Budownictwa Lądowego i Wodnego,

Katedra Mostów i Kolei

marek.kruzynski@pwr.edu.pl

DOI: 10.35117/A_ENG_16_10_01

\section{Twenty years of the Centre for Exploitation of Experimental Track - history, research and technical characteristics}

\begin{abstract}
The article describes the history of the experimental track and premises which contributed to its construction. Technical characteristics of the infrastructure and different solutions of subtrack construction were also presented. Studies carried out on the track in the field of railway were listed.
\end{abstract}

Keywords: Experimental track; Subtrack; Research

\section{Introduction}

New construction solutions in key areas such as: railway rolling stock, pavement, traffic control equipment, electric traction should be characterized by high reliability and efficiency of functioning, which would guarantee full safety of train traffic. These requirements make it necessary to conduct comprehensive and thorough research on conditions similar to the normal exploitation, which can be met with the appropriate disposition of research base. Its necessary component is appropriate experimental track.

Studies on the testing track have the following advantages:

- They are carried out under conditions similar to the normal railway traffic, which does not interfere with them, however, and simultaneously is not disturbed by the test,

- Exploitation conditions, according to the testing requirements, may remain unchanged throughout the study, or may be changed depending on the purpose of research;

- The time required to obtain results is reduced to a minimum (compared to the research on exploited lines) due to quick start of conducting research without interruption. In the case of durability tests, shorten research time results from the fast growth of track loading on the experimental circle which is very important in the research process;

- They allow to accurately determine the conditions in which comparative study are carried out. This enables an objective assessment of the technical level of the object;

- They enable to conduct research in specific technical solutions for a large number of required indicators which cannot be carried out on exploited lines due to the excessive duration of the studies and because of the likelihood of mutual interference of studies and rail traffic as well as mutual risk of security;

- They allow getting fast results, giving possibility to take up the right decisions in investment plans as well as purchase of proven product;

- They accelerate the development of prototypes and their research, which significantly shortens the time needed to start serial production and thus speed up the delivery of finished products. 
The first idea of building the experimental track in Poland emerged in the fifties of the last century. In 1951, the Scientific Research Institute of Railway Olszynka Grochowska was established where the test track was to be located. The neighbourhood of Sochaczew was also proposed because favourable terrain conditions. However, discussions and analyses conducted in this subject in the fifties and sixties were never finalized.

In the seventies, when the Polish passenger and freight railway transport played a significant role, it was returned to the subject. The dominant role of rail transport made that in PKP, qualitative changes in management, organization and transport technologies as well as technical changes were necessary, which would increase the durability and reliability of technical equipment and modernization of structural solutions. These were the main trends in scientific work of the Centre for Research and Technological Development Railway. All modernization, which was intended to introduce in the railways had to be tested in the laboratory and verified under normal exploited conditions. However, it faced always difficulties and inconvenience. Therefore, the next plans about location of experimental track appeared in: Upper Silesia, around Huta Katowice, Desert Błędowska near Wroclaw - Jelcz and Bielawa. Despite the different concepts, the plans were not realized because of economic reasons.

The eighties are the new circumstances favourable for the construction of the track. The type and nature of works carried out by the Centre for Scientific - Technical Railway resulted in the need for research in conditions similar to the normal exploitation of rolling stock and rails. Industries involved in the improvement of railway technology in the production of rolling stock and rails also showed great interest in the construction of a research training ground. After many years of studies and searches for the location of the experimental circle, the neighbourhood around Żmigród was finally selected.

\section{Basic concepts of building a experimental track}

In all the projects that began to appear in the first half of the eighties, it was assumed that experimental district (Figure 1) shall consist of at least two closed track structures, which would create a large and a small circle. These systems must be linked with each other and connected to the railway network. In the composition of the experimental circle should find: interchange station and additional tracks for different purposes, an administration and social building, other objects, and technical positions.

The large circle was intended mainly to conduct comprehensive testing of locomotives, carriages and other rail vehicles with high speeds $(300 \mathrm{~km} / \mathrm{h})$, and research junctions adapted to $200 \mathrm{~km} / \mathrm{h}$. The small circle is primarily a tool to conduct durability tests of tracks, rolling stock and other railway infrastructure. Work station included tracks for measurement carriages, tested rolling stock and heavy test train with 5000 - 6000 gross tons, inspection and by-passing tracks, unloading track for surfacing materials, extraction track with the triangle to rotate rolling stock, additional track with small arches for research of rolling stock. It was also planned to build a special track dedicated for researches for the purpose of military engineering. 


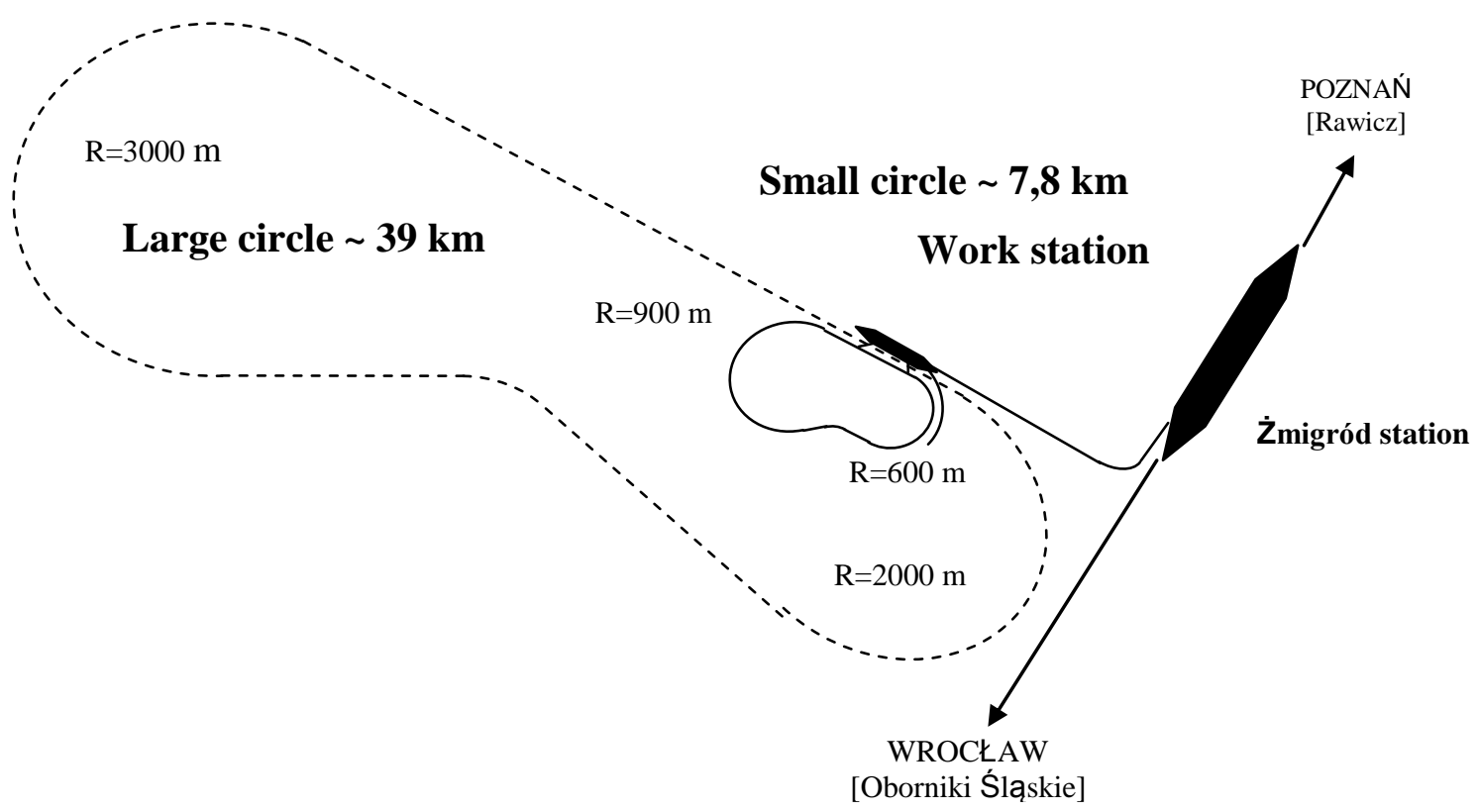

1. Sketch of the proposed Traverse Research Station according to the concept from 1986

\section{Main arguments for the construction of the experimental circle}

The construction of the track was closely linked to the subject of scientific researches carried out in the Central Research Programme - Development No. CBPR 9.3 for the years 1986 - 90. Their main fields that were to serve many useful purposes include:

- increasing the durability of track structure,

- increase the reliability of electric traction power supply,

- improvement of the technical condition of the rolling stock,

- construction of modern carriages and traction vehicles,

- automation of carriages management,

- rationalization of rail traffic,

- modernization and equipment of tracks for general-cargo stations.

For specific technical solutions or finished construction product should be conducted comprehensive studies and measurements of exploited conditions. In this regard, experimental track was the perfect proving ground research particularly for the first four issues, because it ensured comprehensive research of alternative solutions and their comparison, and limited research time to a minimum. The following topics of research in the field of railways included in the program CPBR 9.3 and others not coming to its scope, best justify the purpose of construction of this object:

- Elastic attaching of type SB-3 of rails UIC for concrete sleepers (CPBR government order, in 1989, planned to begin production of 2 million units/year).

- Examination of the service life of rails for high strength; heat treated, naturally hard (alloy) from a continuous casting process (CPBR).

- Research on information series of elastic fastening rails to wooden sleepers (CPBR).

- Research of joints reinforced to rails UIC60 and S49 on wooden and concrete sleepers (CPBR).

- Research on the selection of concrete sleepers at the junction S49-190-19.

- Research of durability of sleepers made from waste wood by gluing and joining inserts. 
- Research on solutions to strengthen the wooden sleepers in the subrail zones (including sleepers made of inferior wood).

- Optimization of collaboration between wheel and rail (defining material properties of rails and wheels).

- Evaluation of the quality of protective layers of tracks: it was planned to carry out a comparative study of protective layers under the ballast used on the station. At several 100meter sections of the small circle were designed layers of medium sand, from stabilized ground and a layer consisting of a non-woven plastic material. For the rest part, loose unsorted material was to be applied as a comparative layer. The study resulted from the need to verify the use and introduction of new ways to strengthen the subgrade. The result of comparisons of the suitability of different strengths of track in terms of their durability and impact on the state of exploited track was to be a verification of applied solutions and setting new directions of developmental researches.

In the place of the testing ground station was selected the neighbourhood of Żmigrod in Lower Silesia. It was associated with the presence of many industrial plants producing rolling stock, among other things: HCP Cegielski Poznań, Zastal in Zielona Góra, PAFAWAG Wrocław, plants in Świdnica, and numerous plants repairing rolling stock. In addition, in the area were located numerous research institutes: University of Wroclaw, Poznań University of Technology, School of Engineering in Zielona Góra, College of Military Engineering Officers in Wroclaw. Other advantages of this location are: flat terrain, small afforestation, and the proximity to the railway station Żmigród, located on the railway line E59 Wroclaw - Poznań. The existing road system also provided convenient transport links with other localities (Figure 2).

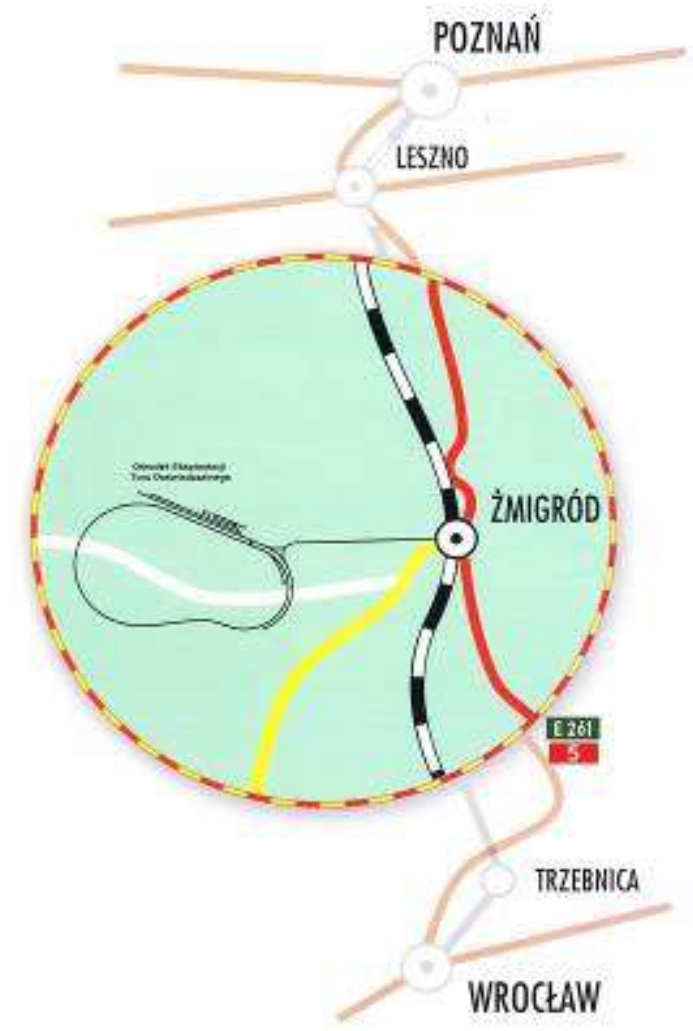

2. Location of experimental track 
An additional prerequisite for the construction of a research training ground which then appeared, in addition to the needs of PKP, was the ability to export of rails and rolling stock, which must meet high technical requirements. Belonging of PKP to organizations such as UIC, ORE, OSŻD and acting in this period by Poland functions of Coordination Centre for the long-term development of railway rolling stock obliged to this project.

\section{Planned scope and course of the building the track}

Initial assumptions claimed at first building of the Small Circle. It was planned to start in 1987 and the full exploitation was to begin in 1990. It was hoped that some of the studies could begin in 1989. The Large Circle was planned in the second order. In the initial phase, it was expected that the comprehensive completion of the whole object will be finished by 1992 . On 09.24.1986, the construction of the Small Circle was incorporated into the CPBR and the funds were granted for this purpose, which, however, proved to be insufficient after upgrading technical and economic assumptions. Therefore, the comprehensive completion of Traverse Research Station was postponed until 1997. The construction began in mid-1987 and was planned to be completed in 39 months, whereas in the next nine months, equipment was to be installed and initial test started up. The construction, however, at some point encountered the big political changes in Poland, as a result of which, there has been a reorganization of all structures, which brought with it a change in the form of financing or even cessation of the plans for two years. This process resulted in the extension of building to 111 months (Fig. 3). The construction can be divided into four stages. The shortest stage but also the most stable, was financed by the Office of Technical and Scientific Progress and Implementation. The work proceeded smoothly according to the realized plan, but 13 May 1989 UPN-T and W stopped funding from CPBR 9. This decision caused that to financing the construction joined DG station, Scientific Research Committee, the Central Fund for the Development of Science and Technology and Huta Katowice, Huta Świerczewski and HCP Cegielski, but the funds were insufficient, and the pace of construction has been decelerated. The realization was focused on the bench to collisions of rail vehicles. The third stage - the hardest because associated with the transformation in the political system and especially in the economy caused a break in financing the project and terminated the work. It was focused on securing the existing infrastructure, the arrangement of the area and finishing works at the bridges. The fourth stage was characterized by very intensive works aimed at completing the task. The funds allocated by DG PKP, and especially material support of manufacturers of paving materials resulted in the intensification of work and the reduction in planned costs (Tabela.1) [1].

Tab.1. History of experimental track building

\begin{tabular}{|c|c|c|c|}
\hline Year & Quarter & Workflow & Periods \\
\hline \multirow{3}{*}{1987} & II & \multirow{3}{*}{$\begin{array}{l}\text { 23.06. } 1987 \text { start of construction, commissioning construction } \\
\text { sites: facilities, access track, temporary stations, } 2 \text { viaducts, } \\
\text { power lines }\end{array}$} & \multirow{8}{*}{$\begin{array}{l}\text { The first period - } \\
\text { building within CPBR } \\
\text { No. 9.3-funded UPNT } \\
\text { and W (50\% of } \\
\text { advancement) }\end{array}$} \\
\hline & III & & \\
\hline & IV & & \\
\hline \multirow{4}{*}{1988} & I & \multirow{4}{*}{$\begin{array}{l}\text { Commenced redemption of lands, rebuilt the station Żmigród, } \\
\text { completed the construction of temporary track, started the } \\
\text { construction of the work station, performed by-passing roads on } \\
\text { four viaducts, started the construction of embankments }\end{array}$} & \\
\hline & II & & \\
\hline & III & & \\
\hline & IV & & \\
\hline \multirow{4}{*}{1989} & I & \multirow{4}{*}{$\begin{array}{l}\text { Completed successively performed documentation PT, built } \\
\text { connecting and exhaust track, built } 2 \text { tracks of the main work } \\
\text { station, the construction of three viaducts was highly advanced }\end{array}$} & \\
\hline & II & & \multirow{6}{*}{$\begin{array}{l}\text { The second period - the } \\
\text { construction financed by } \\
\text { DG PKP, CFR } \mathrm{N} \text { and T } \\
\text { and KBN, partly by Huta }\end{array}$} \\
\hline & III & & \\
\hline & IV & & \\
\hline \multirow[b]{3}{*}{1990} & $\mathrm{I}$ & \multirow{3}{*}{$\begin{array}{l}\text { Completed the construction of a factory, made the position to } \\
\text { study collisions of rail vehicles, removed all collisions at } 40 \text { sites, } \\
\text { postponed the river Krępa for } 1 \mathrm{~km}\end{array}$} & \\
\hline & II & & \\
\hline & III & & \\
\hline
\end{tabular}




\begin{tabular}{|c|c|c|c|}
\hline & IV & & \multirow{4}{*}{$\begin{array}{lr}\text { Katowice } & \text { and } \\
\text { Świerczewski, } & \text { HCP } \\
\text { Cegielski (82\% } & \text { of } \\
\text { advancement })\end{array}$} \\
\hline \multirow{4}{*}{1991} & I & \multirow{4}{*}{$\begin{array}{l}\text { Completed the construction of } 2 \text { viaducts, earthworks on the } \\
\text { circle route, started the construction of a traction substation, } \\
\text { advanced building foundations for poles traction }\end{array}$} & \\
\hline & II & & \\
\hline & III & & \\
\hline & IV & & \multirow{8}{*}{$\begin{array}{l}\text { The third period - a } \\
\text { temporary suspension of } \\
\text { work, elimination of } \\
\text { nuisance building for the } \\
\text { environment ( } 87 \% \\
\text { advancement) }\end{array}$} \\
\hline \multirow{4}{*}{1992} & I & Completed the construction of & \\
\hline & II & stopping of the construction secured 5 viaducts, the by-passing & \\
\hline & III & road, earthworks on the route of the circle, and the construction & \\
\hline & IV & of traction substation & \\
\hline \multirow{4}{*}{1993} & I & \multirow{4}{*}{$\begin{array}{l}\text { Completed the construction of the last viaduct, cleaned up by- } \\
\text { passing and access roads to the fields, abolished nuisance of the } \\
\text { construction to the environment, secured the construction of the } \\
\text { circle }\end{array}$} & \\
\hline & II & & \\
\hline & III & & \\
\hline & IV & & \multirow{12}{*}{$\begin{array}{l}\text { The fourth period - } \\
\text { funded by DG PKP with } \\
\text { the support of industry } \\
\text { (free } \\
\text { material)(97\% shipping } \\
\text { advancement) }\end{array}$} \\
\hline \multirow{4}{*}{1994} & I & \multirow{4}{*}{$\begin{array}{l}\text { Completed work of subgrade and laid paving on the circle, } \\
\text { installed turnouts and rail span, built the track with small arches, } \\
\text { built bypass experimental bridge, advanced electrification, } \\
\text { adaptation of construction base for CNTK }\end{array}$} & \\
\hline & II & & \\
\hline & III & & \\
\hline & IV & & \\
\hline \multirow{4}{*}{1995} & I & \multirow{4}{*}{$\begin{array}{l}\text { Finishing track work, continued electrification, installation of } \\
\text { railway traffic control devices, organization of the site, preparing } \\
\text { the object into exploitation, creation of the Department of } \\
\text { Sustainable CNTK Track Testing }\end{array}$} & \\
\hline & II & & \\
\hline & III & & \\
\hline & IV & & \\
\hline \multirow{3}{*}{1996} & $\mathrm{I}$ & \multirow{3}{*}{$\begin{array}{l}\text { Completed electrification, launched signalling systems, made } \\
\text { technical acceptance of subgrade and other devices, installed the } \\
\text { first trial train weighing } 2,000 \mathrm{t}\end{array}$} & \\
\hline & II & & \\
\hline & III & & \\
\hline
\end{tabular}

\begin{tabular}{l|c|c|c|c|c|c|c|c|c|c|c} 
Plan & & & & & & & & & & & \\
\hline Realization & & & & & & & & & & & \\
\hline & 1986 & 1987 & 1988 & 1989 & 1990 & 1991 & 1992 & 1993 & 1994 & 1995 & 1996
\end{tabular}

3. Plan and implementation of the construction of a testing ground of PKP

\section{Participation of research institutions in the process of construction and exploitation}

Assumed exploitation parameters for the Small Circle indicated that besides the construction of surface adopted in the project and quality of the materials used, the durability of the building structure will be determined by the factors such as the quality of the substructure works, with high accuracy of assembly works and works laying the track, and then the correct finishing of all works. Therefore, it was decided that the quality of substructure works will be controlled by the Institute of Civil Engineering Poznan University of Technology and the Research Institute of Roads and Bridges (Branch Wrocław). Given the expected load which occurs on the track to test, it approached to the studies in an unconventional way. It was decided that it is necessary to extend the scope of the research capacity of CBR determined in the laboratory, studies on granulation determining properties of aggregates, which have a significant effect on the load-bearing capacity and stability of mechanical layers. Due to the type of the used aggregate, compaction studies were also performed according to the modified method of Proctor.

Conditions of acceptance in terms of material types and rules for receiving substructure recognize:

Receiving the material (soil and aggregate)

- Control of the ground used in the construction of the embankment:

- Load-capacity index CBR

- Indicator of multi-granulation

- The sand rate

- Passive capillarity 
- Control of aggregate

- Load index using VSS

- Indicator of multi-granulation

- Abrasion in the drum Devala and Los Angeles

- Absorbability

- Resistance to frost

Reception of correctness in incorporation of ground and aggregates

- Correctness of laying protective layer:

- Degree of compaction and surface layers of the embankment

- Thickness of layer

- Terzaghi's condition at the interface of layers changing its structure

- Load capacity index CBR of track layer for Is $=0.95$

- Verifying the correctness of build embankments:

- Degree of compaction and surface layers of the embankment

- Terzaghi's condition at the interface of layers changing its structure

- Load capacity index CBR layer tracks for Is $=0.95$

- Correctness of laying abscission layer:

- Thickness of layer

- Terzaghi's condition at the interface of layers changing its structure

- Load index using VSS

The results of the research presented in the final report of the geotechnical substructure of Small Circle (IBDiM TW-08195/W-154) can be used for:

- determining the technical parameters of the construction of substructure, whose results are expertise of individual elements of substructure,

- determining the state of the track bed with proposals for changes in technology,execution of works within the scope of the current maintenance, plan to renew changes eliminating causes of excessive deformation changes,

-elaboration of technical documentation of modernization of items including the elimination of the risks of deformation from defects in design, defects in workmanship or material-technology assumptions.

During construction, the most common parameter measured was the rate of compaction, the average value for the protective layer is 1.02 with a standard deviation of 0.02 , and for embankment layer, cut-off and subsoil 1.00 with a standard deviation of 0.04 . The research allowed defining the particle size stability at the interface layer between the embankment and the protective layer, a protective layer and key aggregate layer, as well as key aggregate layer and macadam layer. Since the materials are properly selected they met the condition of rigidity and load capacity. The construction of laboratory control conducted from the beginning enabled the selection of appropriate materials for the construction, verification solutions at the design stage, quality control of work at simultaneous geodetic control. Completed studies at a significantly diversified construction of substructure and the subsoil varied and rich archival material made in laboratory tests, will allow in the future, during fatigue testing, determining deformations that may occur as a result of extreme loads [5]. 


\section{Wykaz warstw i materialów}

Wykaz warstw i materialów

PODLOZZE GRUNIOWE

WARSTWA TLUCZNIOWA

WARSTWA OCHRONNA

WARSTWANASYPU

WARSTWA ODCINAJĄCA

\begin{tabular}{|c|c|c|c|}
\hline Rodzaj warstwy & Material & \multicolumn{2}{|c|}{ Lokalizaça } \\
\hline \multirow{4}{*}{$\begin{array}{l}\text { Worstwa } \\
\text { rucziona }\end{array}$} & 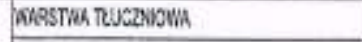 & $6+000$ & $1+501,416$ \\
\hline & 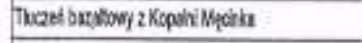 & $2+201,45$ & $7+724,609$ \\
\hline & 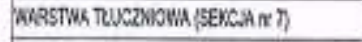 & \multirow[t]{2}{*}{$1+501.418$} & \multirow[t]{2}{*}{24801,45} \\
\hline & 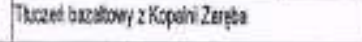 & & \\
\hline \multirow{5}{*}{$\begin{array}{l}\text { VORSTWA } \\
\text { OCHRONA }\end{array}$} & 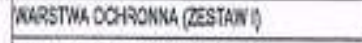 & $0+1000$ & $1+734$ \\
\hline & $20 \mathrm{cn}$ Hascatu kerientego i Sobets & $2+0 \times 5$ & $3+350$ \\
\hline & 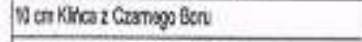 & $5+000$ & $7+124,59$ \\
\hline & 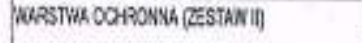 & $1+734$ & $2+275$ \\
\hline & 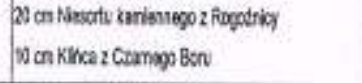 & $3+350$ & $5+2023$. \\
\hline \multirow[t]{3}{*}{ WLESTWANASYYU } & TRESTWU XUSYPU RESTAW D & Detcolo & $3+32$ \\
\hline & Bun Gt z Ramowic & $5+700$ & $7+724,56$ \\
\hline & 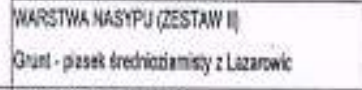 & 3450 & $6+702$ \\
\hline \multirow{10}{*}{ 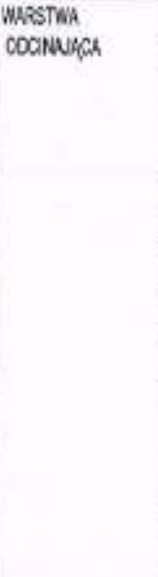 } & \multirow{4}{*}{ 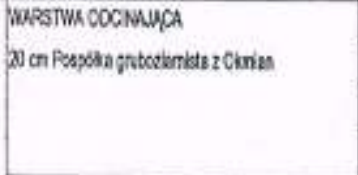 } & $\theta+(0)$ & $0+250$ \\
\hline & & $1+1098$ & $2+103$ \\
\hline & & $\theta+40$ & $T+3 \pi 0$ \\
\hline & & $7+60$ & $7+72,092$ \\
\hline & 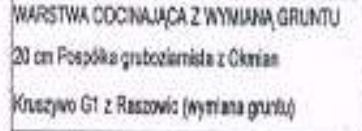 & $7+310$ & $T+635$ \\
\hline & \multirow{4}{*}{ 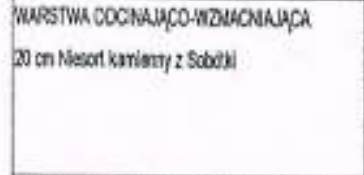 } & $8+500$ & $8+503$ \\
\hline & & $4+100$ & 4003 \\
\hline & & $5+40$ & $6+105$ \\
\hline & & thes & $(+40)$ \\
\hline & 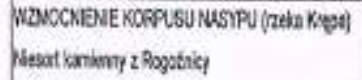 & $\$ 1+00$ & $4+001$ \\
\hline
\end{tabular}

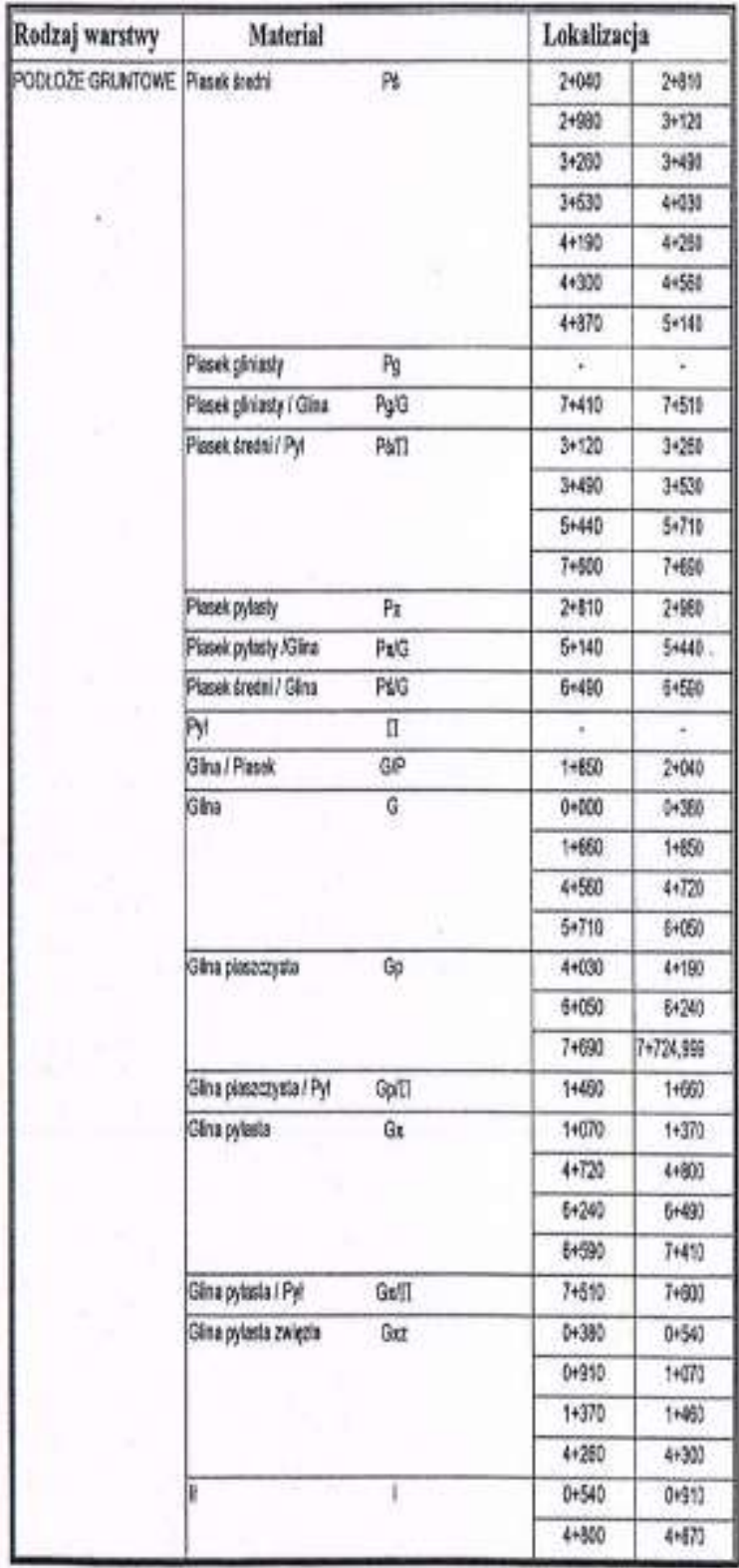

4. Sample geotechnical metric of Small Circle 


\section{Grunt-piasek średnioziarnisty z Lazarowic}

\begin{tabular}{|l|c|c|}
\hline Rodzaj warstwy & \multicolumn{2}{|c|}{ WARSTWA NASYPU - ZESTAW if } \\
\hline Lokalizacja & od & do \\
\hline & $3+350$ & $5+700$ \\
\hline
\end{tabular}

\begin{tabular}{|c|c|c|c|c|c|}
\hline \multirow{2}{*}{ Charakterystyki } & \multirow{2}{*}{ Jedn. } & \multicolumn{4}{|c|}{ Wynik } \\
\hline & & Sredai & Min. & Max. & Odeh. \\
\hline Wskażnik rótnoziarnistości $\mathrm{U}=\mathrm{d}_{d} / \mathrm{d}_{\text {is }}$ & $\cdot$ & 5,6 & 2,7 & 16,6 & 2,9 \\
\hline $\mathrm{d}_{\omega}$ & $\operatorname{mm}$ & 0,811 & 0,200 & 8,800 & 1,248 \\
\hline$d_{t 0}$ & $\mathrm{~mm}$ & 0,146 & 0,059 & 1,850 & 0,252 \\
\hline \multicolumn{6}{|l|}{ Wskażnik mrozoodpornosiei } \\
\hline $\mathrm{U}=\mathrm{d}_{10} / \mathrm{d}_{10}$ & - & 5,6 & 2,7 & 16,6 & 2,8 \\
\hline$z<0,02 \mathrm{~mm}$ & $\%$ & - & - & $\cdot$ & - \\
\hline$d=13,5-0,7 \mathrm{U}$ & $\%$ & 9,6 & 11,8 & 1,2 & 11,5 \\
\hline \multicolumn{6}{|l|}{ Wskaźnilk zlaraowy ukladu warstw } \\
\hline 4. $d_{i s}$ & $\mathrm{~mm}$ & 1,162 & 0,250 & 27,600 & 3,875 \\
\hline $\mathrm{D}_{1}$ & $\mathrm{~mm}$ & 0,125 & 0,090 & 0,190 & 0,032 \\
\hline $4 d_{s s}$ & $\mathrm{~mm}$ & 6,758 & 0,800 & 25,200 & 6,146 \\
\hline Wskażnik zageszczenia Wz & - & 1,00 & 0,95 & 1,15 & 0,04 \\
\hline$w_{\mathrm{gx}}$ & $\%$ & 10,3 & 7,1 & 13,9 & 1.8 \\
\hline $\mathrm{B}_{\mathrm{amax}}$ & $g / \mathrm{em}^{3}$ & 1,820 & 0,087 & 2,008 & 0,224 \\
\hline Wskaznlk noiności CBR & $\%$ & 25,8 & 25,9 & 25,9 & $\cdot$ \\
\hline
\end{tabular}

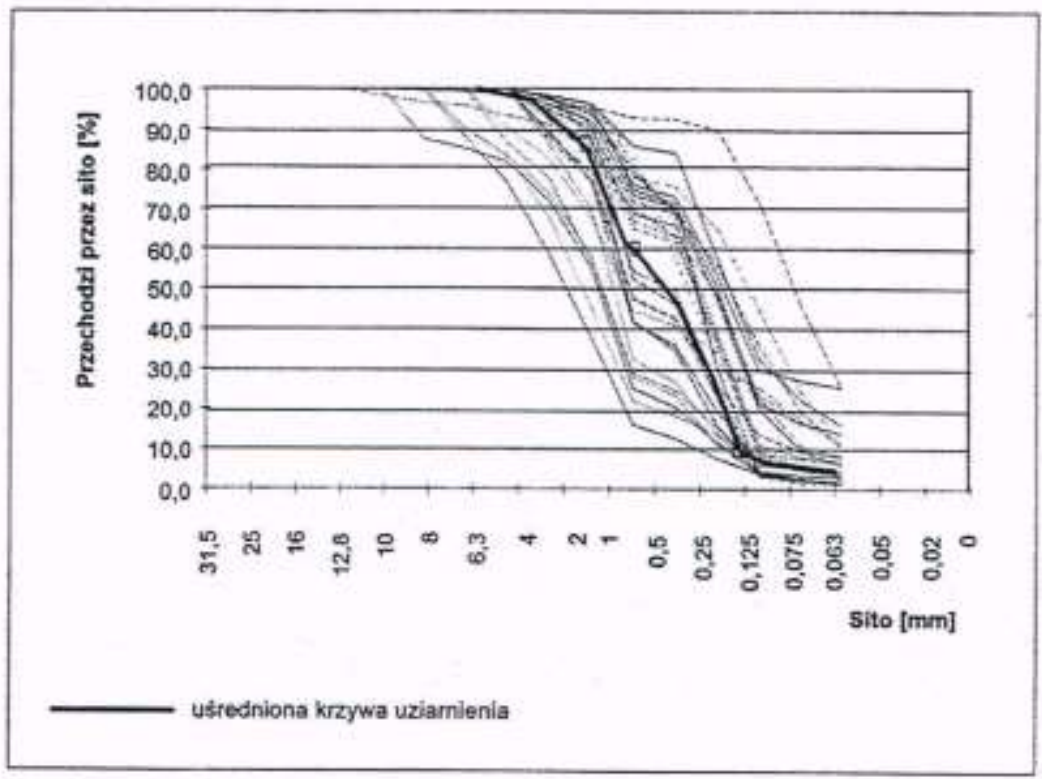

5. Example characteristics and curves of granulation

After more than three years exploitation and a total load of $18 \mathrm{Tg}$, in order to determine the status of the existing subgrade, Institute of Civil Engineering from Wroclaw University of Technology conducted a study subgrade soil compaction of the Small Circle. Sounding was carried out with the light probe of hammer-type ITB with a conical end, approximately every $50 \mathrm{~m}$ alternately on both sides of the track to a depth of $3.0 \mathrm{~m}$. The place of probing adopted in such a way to obtain reliable results for each of 26 sections, and each of the grounds in the subgrade. Samples of grounds were also obtained to check the macroscopic inspection of their kind in the individual layers, and marked drilled level of ground water. Based on the study 
and analysis of the results, it revealed that the ground in the subgrade is very concentrated. Indicators of density in the protective layer are within $0.98 \leq$ Is $\leq 1.01$, for grounds in the embankment $0.94 \leq$ Is $\leq 1.01$. The cutting layer is determined the coefficient in the range $0,90 \leq$ Is $\leq 1,01$ and for subgrade in the embankments it is $0,98 \leq$ Is $\leq 1,01$ [3].

\section{Technical characteristics of the existing object}

The curved, closed shape of the Experimental Circle with the length of $7725 \mathrm{~m}$ is made up of 25 track sections with the length of $300 \mathrm{~m}$ and $225 \mathrm{~m}$ of junction section. The surface is equipped with rails UIC 60 partly on concrete sleepers of various types and of soft and hard wood. By properly chosen location of the different types of sleepers and various types of fastening, the obtained sections of the track are different in terms of design and location in the plan (Fig. 6). This is important in conducting various types of research of pavement. The substructure of the experimental track loop is embankment made of permeable soil (sand, gravel) secured from the top by protective layer (layer filtering of key aggregate and tight layer of unsorted concentrated stone), and the bottom layer cutting from the ground virgin soil (gravel, subgrade and unsorted stones). It was also built several experimental sections where the protective layer used key aggregate from Czarny Bór, the old ballast from Wroclaw Main, medium sand and stabilization made by cement. The essential drainage of subgrade are the side and drain ditches. The experimental track is contactless. It is made of straight sections with lengths of $1313.9 \mathrm{~m}$ and $543.9 \mathrm{~m}$ and arcs of radius $\mathrm{R}=600 \mathrm{~m}$ and $\mathrm{h}=150 \mathrm{~mm}, \mathrm{R}=700$ $\mathrm{m}$ and $\mathrm{h}=115 \mathrm{~mm}, \mathrm{R}=800 \mathrm{~m}$ and $\mathrm{h}=90 \mathrm{~mm}, \mathrm{R}=900 \mathrm{~m}$ and $\mathrm{h}=100 \mathrm{~mm}$. The longitudinal profile of the experimental loop consists of sections located horizontally and on slopes $1 \%$ and $2 \%$. Built-in crossovers are No. 20 and No. 21.Equipment of the objects are also tracks of the work station, which consist of track No. 1 withe the usable length $973 \mathrm{~m}$, the track 3 and 3a with the length of $852 \mathrm{~m}$, the track No. 5 with the usable length of $352 \mathrm{~m}$, the track No. $7-224 \mathrm{~m}$, the ribbed track No. 1c with revision channel of the usable length of $66 \mathrm{~m}$, the exhaust track $8 \mathrm{a}$, which is located in an arc with the radius of $605 \mathrm{~m}$ with the usable length $1000 \mathrm{~m}$ and the tracks included in the triangle to rotate train stock, the track No. 10 in the shape of an arc with the radius of $150 \mathrm{~m}$, the extractor track 8 and the access track No. 1a. The entire track system is shown in Figure 8. The whole building has 12 turnouts. The whole is connected to the railway station Żmigród by the access track No. 101 and 1a, laid partly in disused railway line 317 Żmigród -Wąsosz [4]. 


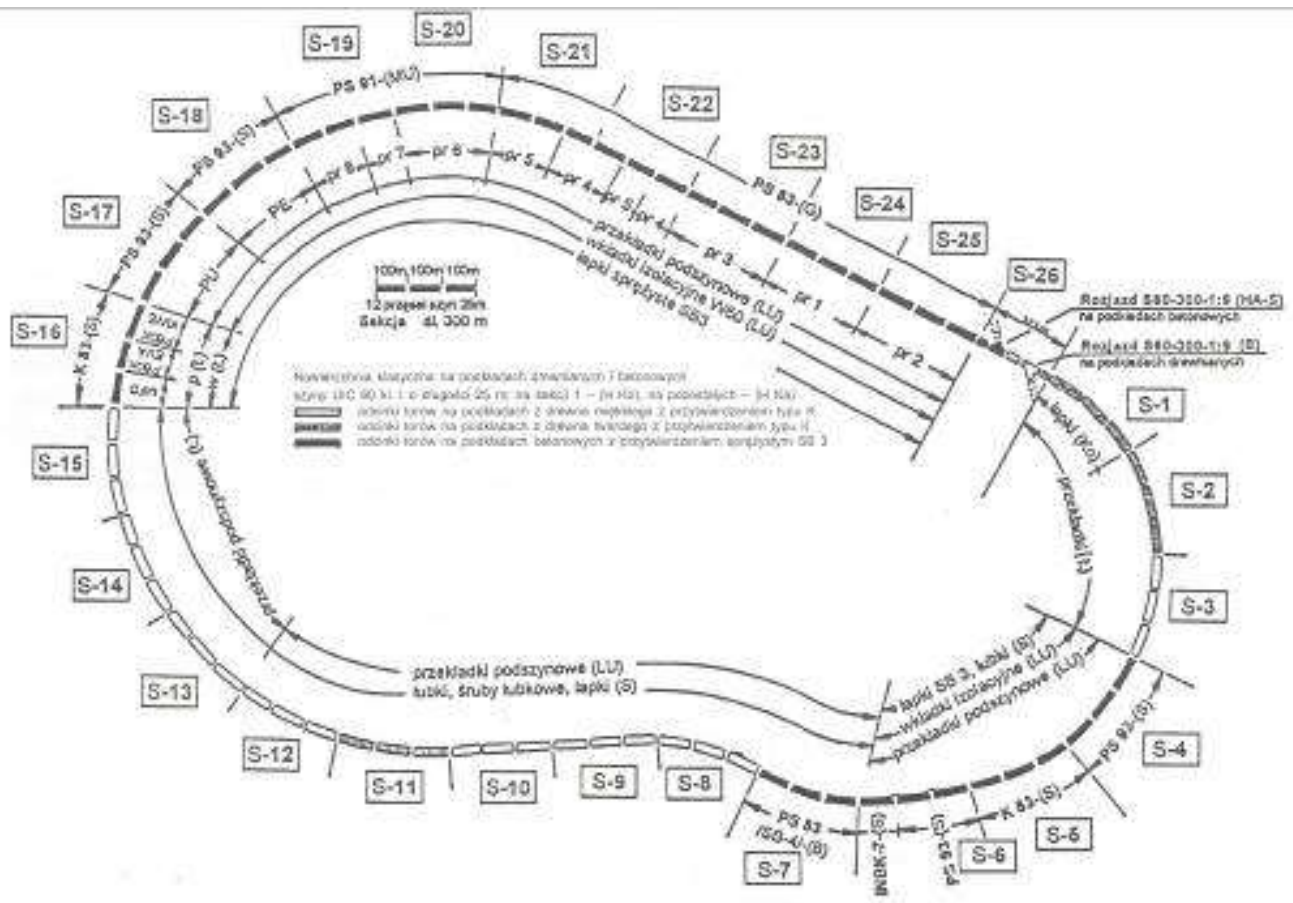

6. Locations of different solutions of pavement structure on separate sections of track No. 2
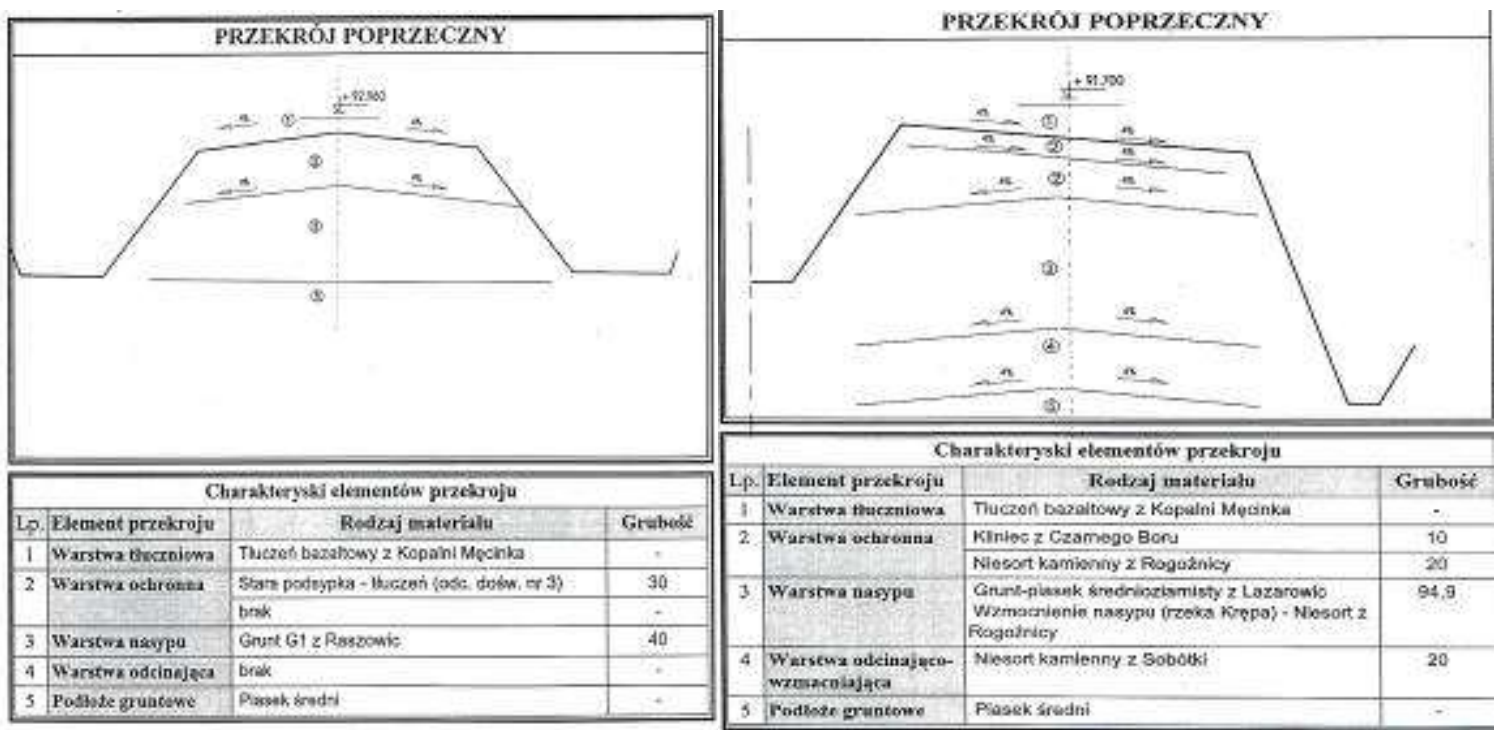

7. Examples of cross-sections of subgrade 

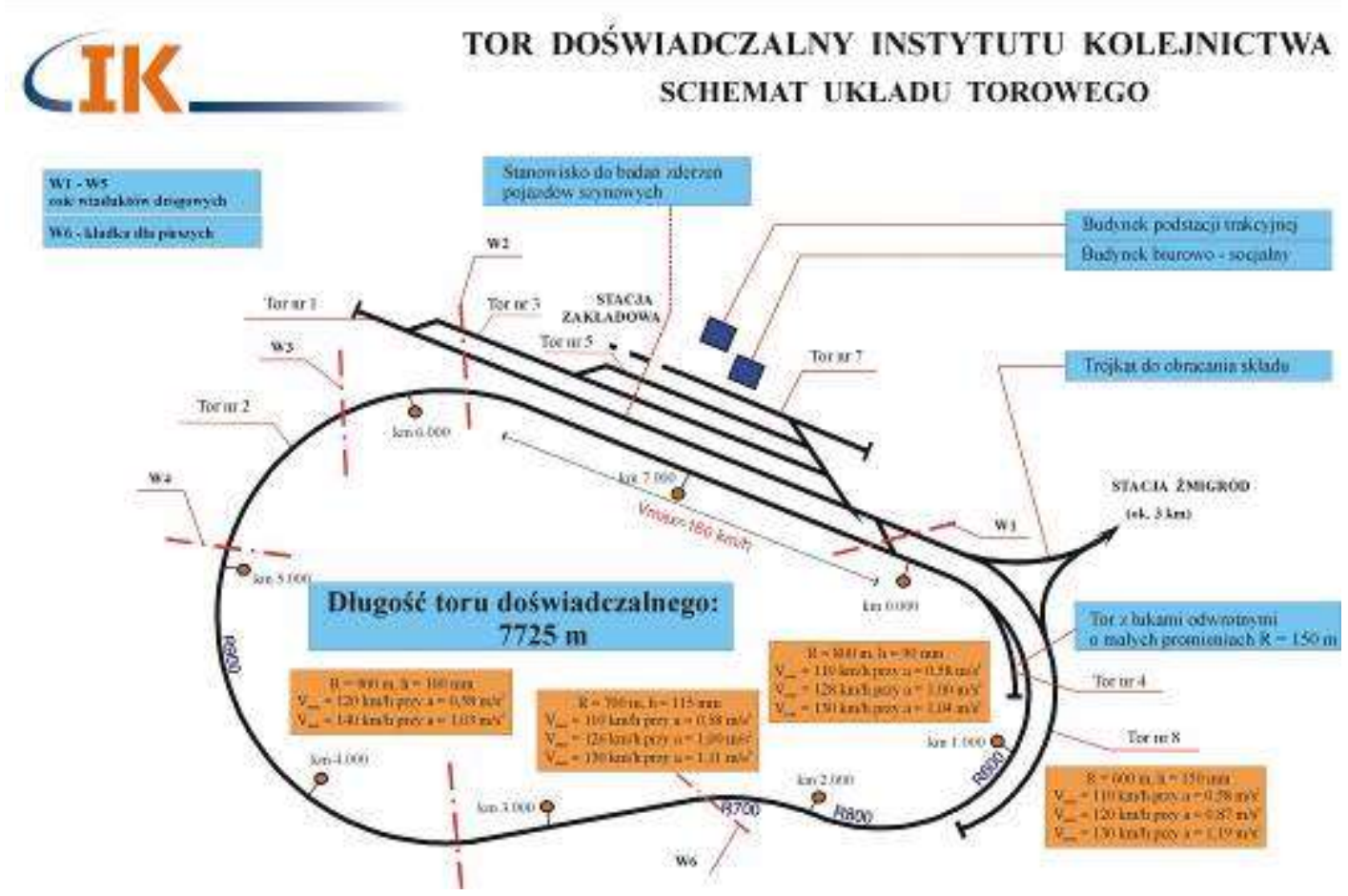

8. Diagram of the track

\section{Research conducted on the testing track}

In the period from 12 September 1996 to 31 December 2015 on the experimental track were completed 446 research projects with a significant excess of tests of rolling stock (Fig. 9). Fig. 10 demonstrates the amount of research on the testing track in the breakdown by years. The researches in the field of railways were conducted in the initial period of exploitation. The following research tasks were carried out:

- Stability studies of crossover UIC 60-300-1: 9 on concrete sleepers.

- Research on concrete sleepers with anchoring SB3.

- Examination of rails UIC produced by Huta Katowice.

- The degradation of ballast in the track experimental exploitation.

- Variation of ground sleepers in the exploitation of the experimental track.

After the four-track exploitation and a total load of $21 \mathrm{Tg}$, work was started under the name: The impact of the operation on the construction of the track and subtrack of the experimental track (9610/32). There were performed tests and measurements of the spatial position of the track, geometric parameters of surface, rail wear and soil compaction of protective layers and soil subgrade. At the same time, were collected the scattered data and the results of measurements made before the start of exploitation. As a result of analysis of the collected materials and measurements it was specified settlement of construction in the sections of the track. The highest average values of total settlement was in the section 7 (ymax $=86 \mathrm{~mm}$ ). The substructure has a relatively low rigidity track with an average module EOI $=126,20$ $\mathrm{MPa}$ in this section. WA weaker substructure, a complicated geometrical arrangement and its rigid structure, which consists of sleepers PS-83, with SB-4 anchoring (B) together with the contacts joined by four-hole shins contribute to an increased in subsidence. Another factor is the high heterogeneity of substructure characterized by the coefficient of variation module $=$ $38 \%[2]$. 


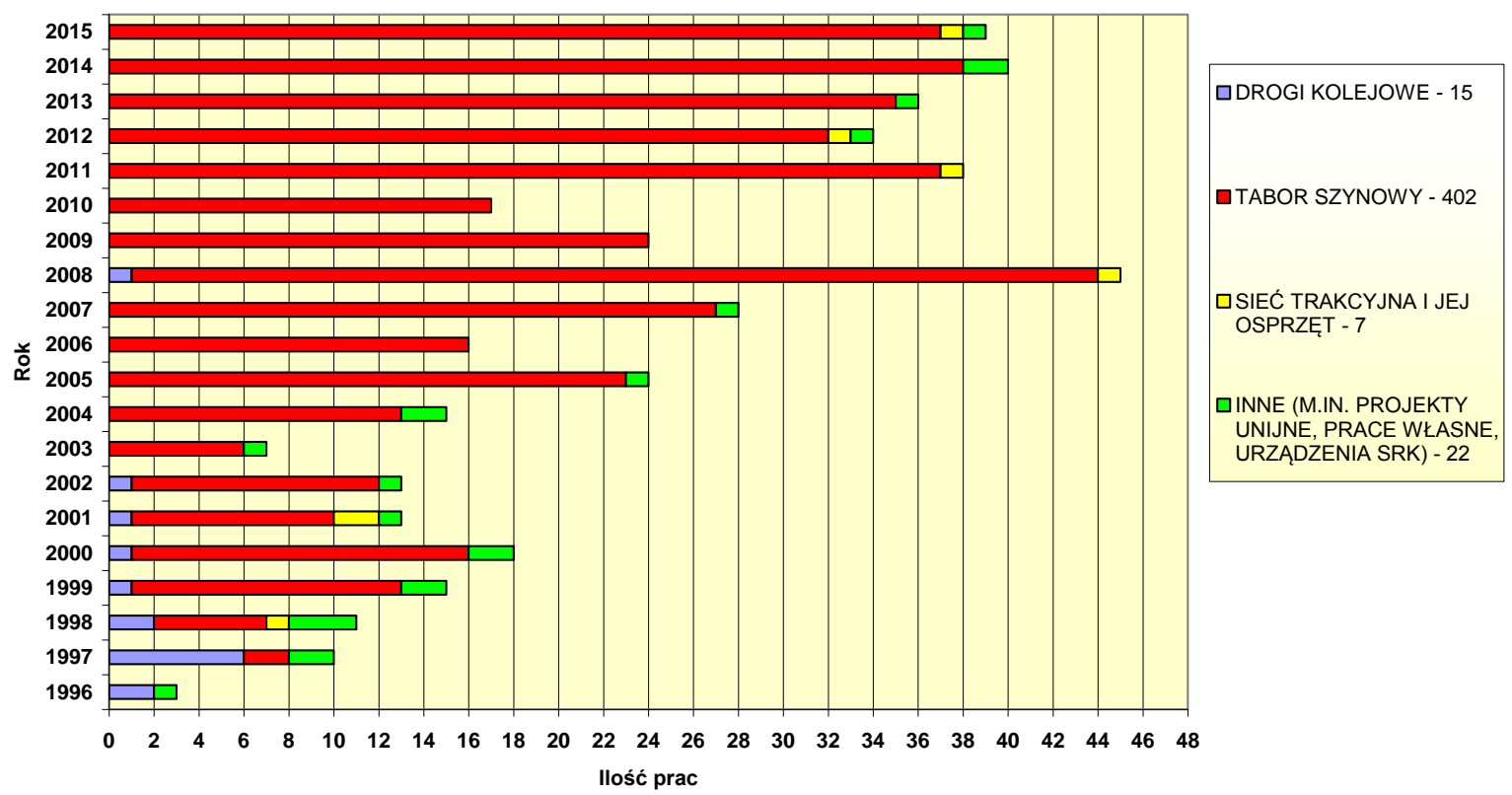

9. Distribution of the research work carried out on experimental circle IK in the years 1996 2015, taking into account the issues examined

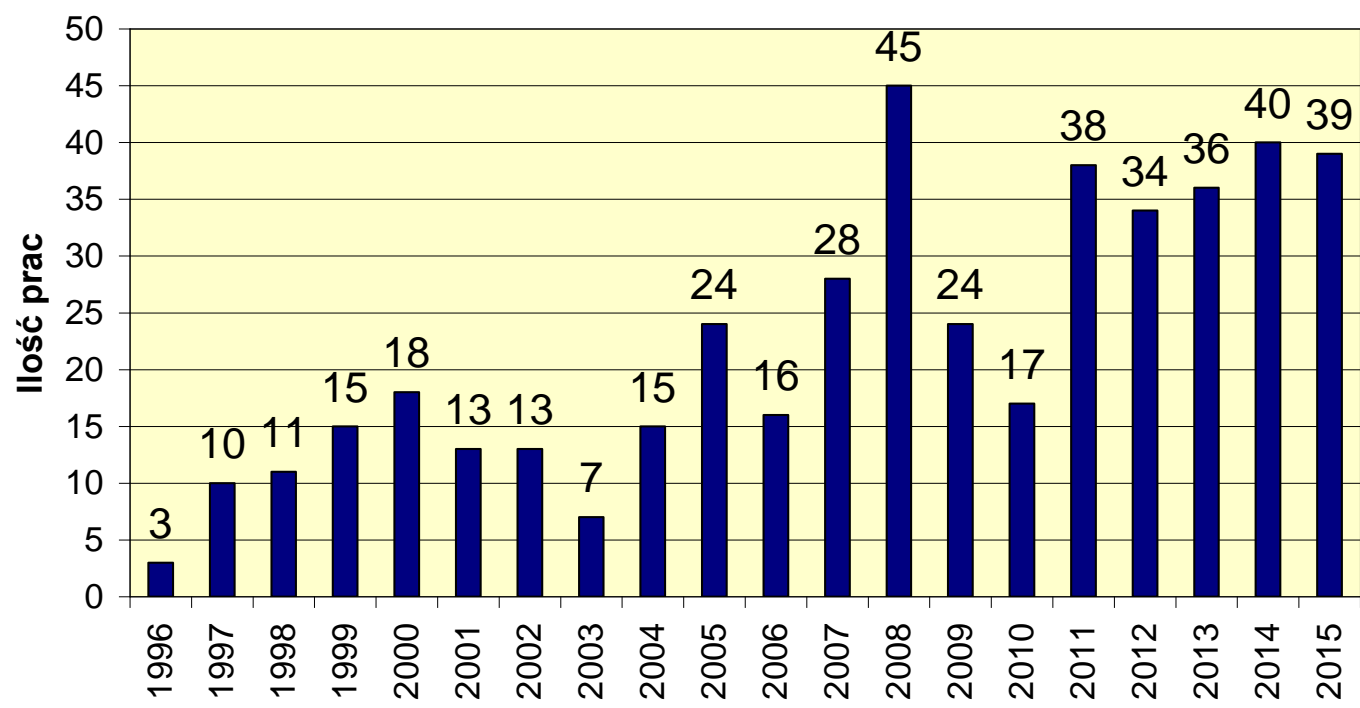

Rok

10. Research carried out on the experimental circle IK in the period 1996-2015.

\section{Repairs and maintenance of the experimental track}

The entire experimental track was designed as a classic track and it was aware that in the future it may be difficult to hold. In 2002, repaired began, rails UIC60 were welded on the length of $6600 \mathrm{~m}$ (559 welds), paths rail on a curve R 600 were postponed, ballast was supplemented along the entire length of the track, which was profiled. At the clear suggestion of IK road service, part of the classic track was left with the length of 1,125 meters in the hope that in the future pavement researches will be conducted and such state will facilitate the exchange of construction. Next works were performed: in 2011 rails were welded over a length of $480 \mathrm{~m}$ (44 welds), and in 2012 was welded track $330 \mathrm{~m}$ (30 splices). In 2014, it was 
started to exchange substrates due to the degradation of sleepers in the section 2, which resulted in the extension of the track in some areas by $15 \mathrm{~mm}$ (Figure 11). Beech sleepers from 1994 were replaced by oak ones on the entire section with a length of $300 \mathrm{~m}$. The track was cut in 4 sites and rails were moved away to allow the dismantling of old sleepers, drawn back ballast to the side and compacted layer below the sleepers. On such prepared substrate track was laid and performed all the operations resulting from this type of technology. Similarly, the work was done in the next year in the section No. 1, where soft sleepers were replaced by oak ones. This year was also welded the last stretch of track in the section No. 7 $315 \mathrm{~m}$ (26 splices). The section 7 equipped with sleepers PS 83 and attachment of SB-4 (B) caused the most difficult problems with removing the fastening. Therefore, all springs were cut with an angle grinder after cutting chambers of shines rails wer welded and elastic feet SB - 7 were mounted. The ongoing works are carried out to maintain embankments, i.e. slope mowing and weeding shelves as well as cleaning drainage ditches draining water from the area of the track (Fig. No. 12).

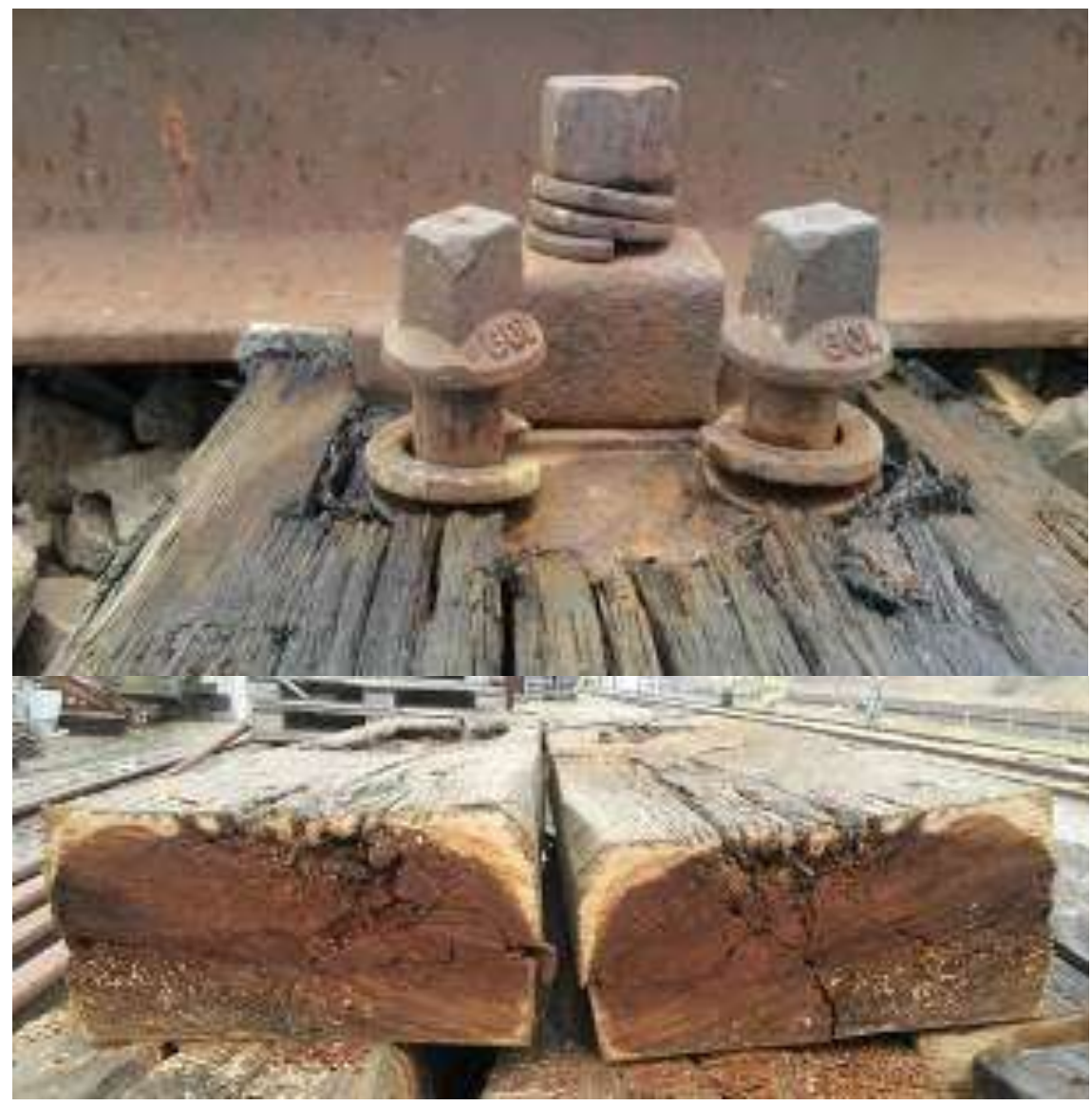

11. Degradation sleepers after 20 years of operation 


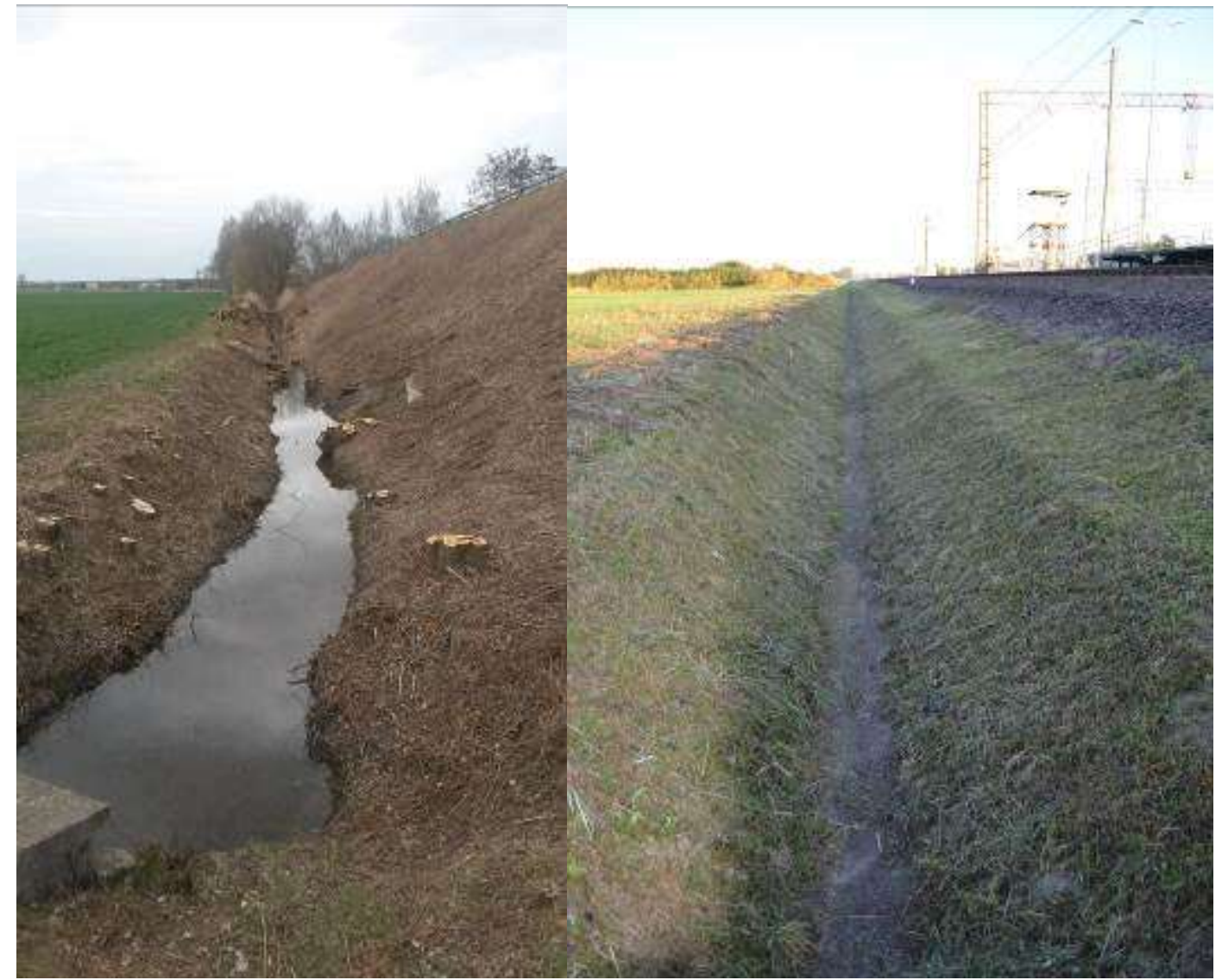

12. Maintenance works at the embankments and drainage ditches

\section{Summary}

In the eighties, during planning durability tests of various elements and components of the railway structure, it was expected to achieve the best results. It was the very important direction of scientific research and to this kind of research the best suited track was the system in the form of a small circle. Designated criterion for attaching the SB-3 is $300 \mathrm{Tg}$ and for rails $800 \mathrm{Tg}$, with a planned annual load of $120 \mathrm{Tg}$ it allowed to shorten the study period. As a comparison, it was assumed the main line with the annual load of $30 \mathrm{Tg}$. Significant reduction of the research time makes a more rapid assessment of the product and hence a faster implementation to the exploitation. The cost of such research is unfortunately very high, and the changes which have passed through PKP made that in a very short time this type of research was abandoned. Real needs made that most studies on the track are rolling stock research. Already in the design stage, it was considered the possibility of postponing to distant years building the Large Circle, and therefore tried to choose the parameters of the Small Circle to allow conducting such a study. Events and circumstances that occurred during the construction of the testing ground caused that Small Circle is the only track system, which for 20 years meets the research needs in real exploiting conditions. At the moment, the gross load is $36.5 \mathrm{Tg}(2000-21.3 \mathrm{Tg})$.

\section{Source materials}

[1] Fiałek Marian Geneza i charakterystyka techniczna Toru Doświadczalnego w Żmigrodzie Prace Instytutu Kolejnictwa , Zeszyt nr 150

[2] Krużyński Marek Wpływ eksploatacji na konstrukcję i podtorze toru doświadczalnego Centrum Naukowo-Techniczne Kolejnictwa 9610/32 
[3] Krużyński Marek, Piotrowski Andrzej Badania Toru Doświadczalnego w zakresie sondowań podtorza wraz $\mathrm{z}$ opracowaniem wniosków Instytut Inżynierii Lądowej Politechniki Wrocławskiej SPR nr 27/2000

[4] Szulc Waldemar Ogólna charakterystyka Toru Doświadczalnego Instytutu Kolejnictwa i rodzaje wykonywanych badań taboru

[5] Wysokowski Adam, Duszyński Andrzej Raport końcowy z badań geotechnicznych podtorza Małego Okręgu na Torze Doświadczalnym k/Żmigrodu IBDiM-TW 08195/W154 